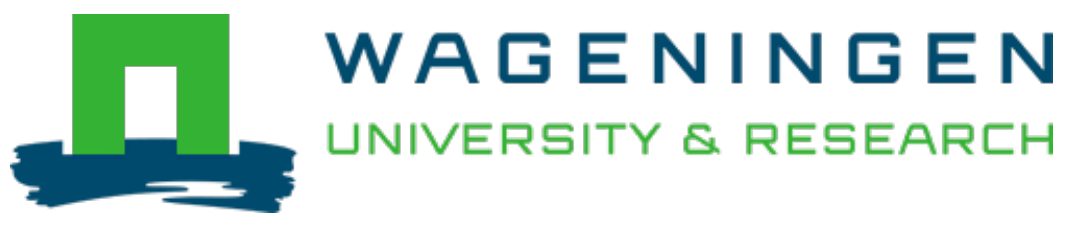

\title{
Future of alkaline-fermented foods for traditional markets
}

Handbook of Indigenous Foods involving Alkaline Fermentation

Nout, M.J.R.; Sarkar, P.K.

https://doi.org/10.1201/b17195-14

This publication is made publicly available in the institutional repository of Wageningen University and Research, under the terms of article $25 \mathrm{fa}$ of the Dutch Copyright Act, also known as the Amendment Taverne. This has been done with explicit consent by the author.

Article $25 \mathrm{fa}$ states that the author of a short scientific work funded either wholly or partially by Dutch public funds is entitled to make that work publicly available for no consideration following a reasonable period of time after the work was first published, provided that clear reference is made to the source of the first publication of the work.

This publication is distributed under The Association of Universities in the Netherlands (VSNU) 'Article $25 \mathrm{fa}$ implementation' project. In this project research outputs of researchers employed by Dutch Universities that comply with the legal requirements of Article $25 \mathrm{fa}$ of the Dutch Copyright Act are distributed online and free of cost or other barriers in institutional repositories. Research outputs are distributed six months after their first online publication in the original published version and with proper attribution to the source of the original publication.

You are permitted to download and use the publication for personal purposes. All rights remain with the author(s) and / or copyright owner(s) of this work. Any use of the publication or parts of it other than authorised under article $25 \mathrm{fa}$ of the Dutch Copyright act is prohibited. Wageningen University \& Research and the author(s) of this publication shall not be held responsible or liable for any damages resulting from your (re)use of this publication.

For questions regarding the public availability of this publication please contact openscience.library@wur.nl 


\section{9 Future of Alkaline- FERMENTED FOODS FOR Traditional Markets}

M. J. Robert Nout and Prabir K. Sarkar

The previous chapters in this book illustrated the wide range of different types of alkaline-fermented foods (AFFs), chiefly produced in many Asian and African countries. We also noticed that whereas some products are produced at industrial scale with a significant level of sophistication, many others are still produced at artisanal scale in small workshops or at home.

What does the future hold in store for these products? Will consumers stay with their food habits and choices or will the demand for AFFs decline? The future of AFFs depends very much on how these products fulfill the expectations of the consumer. Even when we speak of "traditional" markets, these are not static; thus, it is important to be aware of the dynamics of the market.

Consumers' lifestyle is changing due to migration (urbanization), economic, and political developments, communication infrastructures (transport of goods, Internet, and cell phones), and others. Other factors may play a role, such as food sovereignty (Kloppenburg, 2008), i.e., the right of the people to produce, process, and consume the food they prefer.

These aspects point toward the need for a sound knowledge and understanding of the structure and dynamics of national, regional, and local markets. It is important to know and understand the consumers' perception of quality (Hansen, 2005), i.e., what does the consumer expect from a food product in terms of appearance, flavor, taste, nutrition, safety, convenience, etc.? In addition, with what kind of other products must this compete? 
Obviously, market research will be essential to establish requirements for future quality traits of AFFs. Easy availability and conveniently and hygienically packed products at an affordable price will be the keywords.

It was mentioned that there is a diversity of sophistication of AFFs. The existence of commercially successful sophisticated products could inspire product developers to upgrade less developed processes or products into future bestsellers.

Taking Japanese natto as an example (Kiuchi and Watanabe, 2004), we see a product that is produced at an industrial scale, fermented with selected starter cultures under hygienic conditions, and packaged to protect the product and to facilitate supermarket retailing. at an affordable price level. Combined with its perceived healthiness, it is hard to imagine that natto would disappear from the Japanese market. In contrast, the level of quality of this product enables it to travel around and get customers in other continents. Like natto, several other AFFs of high standard can be mentioned. On the other hand, a range of AFFs is still manufactured at household- or small industrial-scale with a minimum of packaging, quality, and safety assurance. It will be a business opportunity to upgrade such products and prepare them for a next-generation market.

Upgrading of traditional fermented products has been advocated (Nout, 1992; Achi, 2005). This can have various purposes such as achieving a constant and superior quality, a more convenient (timesaving) product, safe and produced under hygienic conditions, having a prolonged shelf life.

A critical evaluation of the product's "unique selling points" should be part of such upgrading. What is the essence: a particular and complex flavor, perceived healthiness, or a special texture? Product versions for the future should deliver authenticity (Casey et al., 2008) in a modern package comprising safety, shelf life, and convenience at an affordable price. They should not be associated with negative aspects such as poverty or amateurishness.

Food legislation, which is one of the most severe trade barriers, is a great burden for the AFF industry, and the governments in each of the producer countries will have to assist the producers to guarantee the quality and safety of such foods by every possible means. It is also necessary to protect the indigenous technologies in producing these 
foods by applying legal tools like intellectual property right (IPR) and sharing of benefits with the people producing the indigenous foods in respective countries (Pardey, 2001; Van der Meulen and Van der Velde, 2004; Zilberman and Kim, 2011).

\section{References}

Achi, O.K. 2005. The upgrading of traditional fermented foods through biotechnology. African Journal of Biotechnology 4: 375-380.

Casey, M.G., Isolini, D., Amrein, R., Wechsler, D., and Berthoud, H. 2008. Naturally occurring genetic markers in lactobacilli and their use to verify the authenticity of Swiss Emmental PDO cheese. Dairy Science and Technology 88: 457-466.

Hansen, T. 2005. Understanding consumer perception of food quality: The cases of shrimps and cheese. British Food Journal 107: 500-525.

Kiuchi, K., and Watanabe, S. 2004. Industrialization of Japanese natto. In Industrialization of Indigenous Fermented Foods, 2nd ed., ed. K.H. Steinkraus, pp. 193-246. New York: Marcel Dekker.

Kloppenburg, J. 2008. Seeds, Sovereignty, and the Vía Campesina: Plants, Property, and the Promise of Open Source Biology. Proceedings, Workshop on Food Sovereignty: Theory, Praxis and Power. St. Andrews College, University of Saskatchewan, Saskatoon, Saskatchewan, Canada: November 17-18, 2008.

Nout,M.J.R.1992.Upgrading traditional biotechnological processes. In Applications of Biotechnology to Traditional Fermented Foods. Report of an ad-hoc panel of the Board on Science and Technology for International Development, eds. E.L. Gaden, M. Bokanga, S. Harlander, C.W. Hesseltine, and K.H. Steinkraus, pp. 11-19. Washington, DC: National Research Council.

Pardey, P.G. 2001. The Future of Food. Washington, DC: International Food Policy Research Institute.

Van der Meulen, B., and Van der Velde, M. 2004. Food Safety Law in the European Union. Wageningen, The Netherlands: Wageningen Academic Publishers.

Zilberman, D., and Kim, E. 2011. The lessons of fermentation for the new bioeconomy. AgBioForum 14: 97-103. 
